\title{
Arabic vs. Greek: the Linguistic Aspect of the Jerusalem Orthodox Church Controversy in Late Ottoman Times and the British Mandate
}

\author{
Konstantinos Papastathis
}

The Orthodox Church of Jerusalem has had a continuous historical presence in Palestine, recognized by the Fourth Ecumenical Council of Chalcedon (451) as the fifth See in the hierarchy of the Christian Church. It enjoys extensive custodianship rights over the Holy Places according to the so-called status quo agreement, and up until the beginning of the nineteenth century, the great majority of the local Christians belonged to the Orthodox creed. From early Ottoman times, the patriarchate was institutionally structured as a monastic brotherhood. This means that the Patriarch, i.e., the Head of the Fraternity, exercises more or less absolute power over all the affairs of the institution. Moreover, during Ottoman times the Patriarchate acquired an ethnically Greek character, to the detriment of the other national Orthodox groups, and especially the indigenous population. Theoretically any Orthodox individual can become member of the brotherhood. In practice, however, since the midnineteenth century the basic criterion for admission to the Brotherhood has been loyalty to the Greek national idea. Overall, the Arab Orthodox movement represented the great majority of the native lay members of the Church from all over Palestine. It was closely related to the Arab national cause, which explains partially its close bonds with the Muslim element of the population as well. In the Mandate period, the native Orthodox were organized in local clubs and were represented at a central level by the Arab Orthodox Executive, except of a small minority that formed the so-called "Moderate party." The Arab Orthodox viewed the Greek rule as cultural imperialism and demanded their emancipation from Greek control, as well as the abolishment of the centralized structure of the institution via Arab inclusion in decision-making processes. ${ }^{1}$ Overall, the Arab Orthodox demands were for: a) the establishment of a

1 'A. al-Aḥad al-Shāfī, Lamḥa ta'rīkhiyya fi akhawiyyat al-qabr al-muqaddas al-yūnānīya (Beirut, 1893) [translated by Michel Najim, An Historical Glance at the Brotherhood of the Holy 
mixed council for the administration of communal affairs, including finances; b) the free admission of Arab Orthodox people to the patriarchal organization; and c) active participation in the electoral processes of the high clergy. The role of Russian diplomacy and religious apparatus in the affair was crucial, and fuelled the intercommunal division along ethnic lines as a means to strengthen the Russian position with regard to the inter-Orthodox power competition, as well as to promote Saint Petersburg strategic goals in relation to the Ottoman Empire. ${ }^{2}$

The aim of this chapter is to contextually elaborate on the linguistic aspect of this controversy, namely the congregation's endeavour to upgrade Arabic to a 'higher' status language, on equal footing with Greek. ${ }^{3}$ In particular, I examine the demands of the indigenous congregation to use Arabic as the working language in education, Church liturgy and administration, which was viewed as an act of resistance to Greek linguistic dominance. In other words, I elaborate on the claim to fill the gap between on the one hand language ideology, i.e., Arabic as a central factor in the respective nation-building process, being a unifying element between the religiously diverse Palestinian Arab collective agent, and on the other hand language practice, i.e., the primacy of Greek within the Church institution imposed from the outsider clerical establishment, and effectively the use of Arabic as a second-order language despite being the standardized language of the native population. My thesis is that the Greek officials were not in principle unwilling to accept the use of Arabic, and actually they did as long as it did not work as the breeding ground for

Sepulcher (California, 1996)]; P.J. Vatikiotis, "The Greek Orthodox Patriarchate of Jerusalem between Hellenism and Arabism," Middle Eastern Studies 20 (1994): 916-929; Daphne Tsimhoni, "The Greek Orthodox Patriarchate of Jerusalem during the Formative Years of the British Mandate in Palestine," Asian and African Studies 12 (1978): 77-121; Sotiris Roussos, "The Greek Orthodox Patriarchate and Community of Jerusalem," in The Christian Heritage in the Holy Land, edited by A. O'Mahony, G. Gunner and K. Hintlian (London, 1995): 211-224; Sotiris Roussos, "The Greek Orthodox Patriarchate and Community of Jerusalem: Church, State and Identity," in The Christian Communities in Jerusalem and the Holy Land: Studies in History, Religion and Politics, ed. A. O'Mahony (Cardiff, 2003): 38-56; Sotiris Roussos, "Eastern Orthodox Perspectives on Church-State Relations and Religion and Politics in Modern Jerusalem," International Journal for the Study of the Christian Church 5 (2005): 103-122.

2 Abdul Latif Tibawi, Russian Cultural Penetration of Syria-Palestine in the Nineteenth Century (London: Luzav and Co., 1966); Elena Astafieva, "La Russie en Terre Sainte: le cas de la Société Impériale Orthodoxe de Palestine (1882-1917)," Cristianesimo nella Storia 24 (2003): 41-68; Derek Hopwood, The Russian Presence in Syria and Palestine, 1843-1914: Church and Politics in the Near East (Oxford: Clarendon Press, 1969).

3 Tinatin Bolkvadze, "Eastern Christian Tradition and the Georgian Language," in Explorations in the Sociology of Language and Religion, edited by Tope Omoniyi and Joshua A. Fishman (Amsterdam/Philadelphia: John Benjamin Publishing House, 2006), 6o-67. 
challenging their own power over the patriarchal affairs. However, in practical terms this norm meant that language worked as a criterion for defining the alien in-group, whose mother-tongue was Greek and which thus could become a member of the Brotherhood, from the native outgroup, who spoke Arabic and whose members thus were eligible only to become parish priests without having the possibility to advance their careers. Subsequently, whereas from a political perspective Arabic worked as an inclusive element for the local Arab Orthodox in the dominant Muslim social body, it became the reason for exclusion from the institutional church organization.

Accordingly, the research questions to be addressed are:

1. How was Arabic used within the Jerusalem Patriarchate, and how did the unequal status of Arabic vis-à-vis the Greek language contribute to the construction of the Arab Orthodox collective identity?

2. What were the underlying reasons for Greek religious establishment for rejecting the Arab claims?

Besides the published public records, Church documents and secondary literature, this chapter builds on primary sources from the British National Archives, the Greek Foreign Ministry, the Israel State Archives, and the Orthodox Patriarchate of Jerusalem. The method used for elaborating the material is built on the historical-critical paradigm.

The chapter is divided into three parts: (1) The context within which the Arab Orthodox movement was developed; (2) The stance of the Greek clergy, and (3) the role of language in the Arab Orthodox cause, to be followed by a Conclusion.

The number of Jerusalem Orthodox was estimated to be 1,400 individuals in 1800; 1,850 in 1850; 5,000 in 1900; and 5,945 in 1922. Throughout this time, the Orthodox Church had the most members of any Christian body, comprising about $10 \%$ of the city's total population. ${ }^{4}$ There is no concrete demographic evidence with regard to the whole of the Palestine region in Ottoman times. According to the 1922 census, the Orthodox congregation had 33, 369

4 Yehoshua Ben-Arieh, "Patterns of Christian Activity and Dispersion in Nineteenth Century Jerusalem," Journal of Historical Geography 2,1 (1976): 50-51. 
members, forming $45 \%$ of the total Christians. ${ }^{5}$ From the mid-nineteenth century onward a wave of Greek immigrants from both the Ottoman Empire and the Greek state settled in Jerusalem in search of employment. This group did not integrate into the dominant community, despite its close contact with the local Orthodox Arabs, but kept its separate Greek identity and loyalty to the national centre. ${ }^{6}$ On the one hand, the two groups had a common religious identity and in some cases shared the same churches, where both languages were used in religious ceremonies. On the other hand, many Greek residents spoke their mother tongue as their first language, and attended mass, where Greek was used exclusively; many of them were settled in a delimited area of Jerusalem (i.e., the so-called Greek Colony), sent their children to different schools, and frequented different social clubs. In short, the fact that the two groups had close links between them did not imply their fusion into a cohesive communal whole, but they actually remained separated from one another. ${ }^{7}$ The existence of the Greek group in Jerusalem was not related to the controversy between the Arab congregation and the Greek religious establishment, because the diaspora group did not work as a pool for recruiting members for the Brotherhood; nor did the hierarchy plead its authority or base its arguments for the patriarchate's supposedly Greek character on the presence of the city's Greek diaspora. In short, any identification between the Brotherhood and the ethnic Greek community in Jerusalem is not historically substantiated. Of course this does not exclude the interaction between the two actors, which was very close especially in the field of education. However, the Greek Brotherhood/Arab congregation divide was an affair strictly of the hierarchy, not the war of the Greek diaspora.

This dispute dates back to the nineteenth century. It was a result of social restructuring and the formulation of a new ideological frame within the multiethnic Orthodox community after Tanzimat, leading to the gradual transformation of this community from a coherent collective group (the Rum-Millet) into a fragmented cluster of antagonistic national movements (Greek vs. Bulgarian; Greek vs. Arab) with a shared religious affiliation. In turn, this process led to the nationalization of the ecclesiastical structures, with the development of 'separatist' movements within the Church, which was transformed from an

5 J.B. Barron, Palestine: Report and General Abstracts of the Census of 1922 (Government of Palestine, 1923).

6 Merav Mack, Angelos Dalachanis, and Vincent Lemire, "Matrimony and Baptism: Changing Landscapes in Greek (Rum) Orthodox Jerusalem (1900-1940)," British Journal of Middle Eastern Studies 45,3 (2018): 443-463; online Jan. 2017: 5-8.

7 Merav Mack, "United by Faith, Divided by Language: The Orthodox in Jerusalem," in the current volume. 
imperial institution into ethnic-based religious jurisdictions. An important development in this direction was the institutionalization of the so-called General or "National" Regulations of the 'Rum-Millet'(1862), which triggered the partial 'democratization' of communal operation. ${ }^{8}$ Involving the laity in the decision-making process proceeded via the creation of the Mixed Councils, composed of both clerics and lay representatives. Consequently, there was a transition of power from the religious bureaucracies to the lay elites. ${ }^{9}$

However, although these regulations were applied in the Patriarchate of Constantinople and later in that of Antioch, they were not accepted by the high clergy of Jerusalem. The normative ground put forward for their rejection was the monastic structure of the institution. This meant that the patriarchate was recognized by law to be in actual terms a Monastery. As such, the congregation could not be entitled to rule an institution whose system of administration, as defined by Canon and the Ottoman Civil Law, gave this right only to its friars. This aspect of the operation of the Jerusalem patriarchate constitutes its difference with the patriarchates of Constantinople and Antioch, which due to their community-centred internal structure were free to open the doors to the creation of the Mixed Councils. ${ }^{10}$ On the other hand, in practical terms the Regulations were rejected because the hierarchy viewed them as a potential threat to the Greek rule, despite the fact that the millet system did not imply a national grouping, but rather had a religious meaning indicating the Orthodox community per se. ${ }^{11}$ As the British Commission argued, there was no legal Ottoman document regarding the Jerusalem Church distinguishing between 'Greek' and 'Arab' - both were considered 'Rum.'12 From the Greek perspective, the distinction between 'Greek' and 'Arab' in national terms (based on the

8 George Young, Corps de Droit Ottoman, Vol. II (Oxford: Clarendon Press, 1905), 21-34.

9 Demetres Stamatopoulos, Metarrythmisi kai ekkosmikeusi: pros mia anasynthesi tis historias tou Oikoumenikou Patriarcheiou ton 190 aiona [Reformation and secularization: towards a reformulation of the history of the Ecumenical Patriarchate in the 19th century] (Athens: Alexandria, 2003).

10 Kallistos Miliaras, "Character and Composition of the Patriarchate of Jerusalem," in Report of the Commission Appointed by the Government of Palestine to Inquire into the Affairs of the Orthodox Patriarchate of Jerusalem, edited by Anton Bertram and Harry C. Luke (London: Oxford University Press, 1921), 284-291.

11 Paraskevas Konortas, Othomanikes theoriseis gia to Oikoumeniko Patriarcheio, 17os - arches $200 u$ aiona [Ottoman vetting concerning the Ecumenical Patriarchate, 17th - beginning of the 2oth century] (Athens: Alexandreia, 1998), 303-315.

12 Anton Bertram and John W.A. Young, The Orthodox Patriarchate of Jerusalem: Report of the Commission Appointed by the Government of Palestine to Inquire and Report upon Certain Controversies between the Orthodox Patriarchate of Jerusalem and the Arab Orthodox Community (London: Oxford University Press, 1926), 58-78. 
idea that within the modernist framework they represented diverse political aspirations and antagonistic collective loyalties on the basis of different senses of civic belonging) was in practice developed after the first quarter of the nineteenth century. Authors who wrote during this period, such as Neophytos, Maximos, and Prokopios, explicitly refer to the "Arab Orthodox," differentiating them from the "Greek." The paradox is that while 'Greek' is identified with the 'Rum,' the 'Arab Orthodox' are also considered to be part of the 'Rum. ${ }^{13}$ On the other hand, for the Greeks learning Arabic was a sign of 'degradation.' ${ }^{14}$ As both the 'nationalization' and the 'democratization' of the Jerusalem Church were objected to by the same opponent, namely the Greek establishment, the two processes gradually collapsed into one. The 'Arabization' of the Patriarchate was perceived as a central stage for 'secularizing' the ecclesiastical administration, while the 'reformation' of power structures within the religious organization was presented as an important step towards the fulfilment of the Arab Orthodox national programme. ${ }^{15}$

In this regard it should be noted that the congregation did not view this struggle, in its first stages, as part of a broad Arab national movement (which in any case did not exist in the nineteenth century), but mainly represented the quest for secularizing the communal operation. In other words, it had an ethno-religious character, reflecting the power game between two distinct collective bodies within the same community, but did not represent a 'national' cause in the sense that the two groups (the Greek hierarchy and the Arab congregation) were not viewed as antagonistic political subjects championing diverse national ideologies. Considering nationalism as the nodal point of the Arab Orthodox cause before the early twentieth century, or of the Greek Brotherhood before the mid-nineteenth century, seems to be more of a social projection than a historical reality. Assessing the history of the lay community in Ottoman times on the basis of an analytical framework (i.e., modern nationalism) that did not apply to the social conditions at the time seems problematic. The establishment of the Greek rule was the outcome of religious colonialism of the 'metropolis' towards the 'periphery', namely the intrinsic force of Constantinople's religious elites to expand their authority over the other church jurisdictions (Churches of Antioch, Jerusalem, etc.). This process became culturized, i.e., it was founded on orientalist stereotypes

13 Athanasios Papadopoulos-Kerameus, Analekta hierosolymitikēs stachiologias (Petersburg) II (1894), 408; III (1897), 37-38, 55, 246, 466.

14 Hopwood, The Russian, 38.

15 Konstantinos Papastathis, "Religious Politics in Mandate Palestine: The Christian Orthodox Community Controversy in the Thirties," British Journal of Middle Eastern Studies 43,3 (2016): 265 . 
representing the native Orthodox as inadequate to assume religious office. ${ }^{16}$ This is why the detachment of Jerusalem from the Ecumenical patriarchate, as well as the deconstruction of the negative portrait of the native Christian created by the Greek ecclesiastics, were considered to be two of the most critical stakes for the overall development of Jerusalem church in the nineteenth century. It seems, therefore, more appropriate historically to place the congregation's struggle in the name of Arab nationalism after the Young Turks period. ${ }^{17}$ This representation of the hierarchy as the foreign Greek usurpers of the Arab cultural patrimony crystallized after the Great War and the creation of the new collective subject, i.e., a common Palestinian national identity. ${ }^{18}$ The Orthodox elites, identifying their cause with the broad national movement, contributed heavily towards the development of mass literacy and the 'print elevation' of Arabic via the newspapers al-Quds, al-Karmil and Filasțin, which heavily questioned Greek rule and opposed Zionism. ${ }^{19}$ Arabic being the shared medium of expression, it worked as a central unifying element between the Christian and Muslim populations, and was a core element in the diversification of the collective body in relation to both colonialism and what Sakakini labelled as the tyrannical and corrupted Greek establishment. ${ }^{20}$

The Arab Orthodox struggle was directly linked to language. The clergy spoke Greek, a language allocated the virtue of being sacred, but which the congregation could not understand. Language, being the differential element, worked as a core criterion for the gradual construction of a distinct identity: that of the

16 Konstantinos Papastathis, “Constructing the 'intra-communal out-group': the Greek religious imperialism and the Arab Orthodox 'quantité négligeable," in Middle Eastern Christians and Europe: Diasporas - Relations - Entangled Histories, edited by Andreas Schmoller (Berlin et al.: Lit, forthcoming).

17 Konstantinos Papastathis and Ruth Kark, "Orthodox Communal Politics in Palestine after the Young Turk Revolution (1908-1910)," Jerusalem Quarterly 56/57 (2014): 118-39.

18 Noah Haiduc-Dale, Arab Christians in British Mandate Palestine: Communalism and Nationalism, 1917-1948 (Edinburgh: Edinburgh University Press, 2013); Laura Robson, "Communalism and Nationalism in the Mandate: The Greek Orthodox Controversy and the National Movement," Journal of Palestine Studies XLI (2011): 6-23.

19 Salim Tamari, "Issa al Issa's Unorthodox Orthodoxy: Banned in Jerusalem, Permitted in Jaffa," Jerusalem Quarterly 59 (2014): 16-36; Noha Tadros Khalaf, Les Memoires de Tssa al Issa:Journaliste et Intellectuel Palestinien 1878-1950 (Paris: Editions Karthala, 2009), 61-64; Michael Bracy, Printing Class: Isa Al-Isa, Filastin, and the Textual Construction of National Identity, 1911-1931 (Lanham: University Press of America, 2011), 19-40.

20 Khalil Sakakini, The Diaries of Khalil Sakakini. Volume II: Orthodox Renaissance, World War I, Exile to Damascus, ed. Akram Mousallam (Ramallah: Khalil Sakakini Cultural Centre, and the Institute for Jerusalem Studies, 2004); Elie Kedourie, "Religion and Politics," in The Chatham House Version and Other Middle Eastern Studies (Chicago: Ivan R. Dee, 2004), 317-342; Nadim Bawalsa, "Sakakini Defrocked," Jerusalem Quarterly 42 (2010), 5-25. 
lay Orthodox, who spoke Arabic. Within the context of the developing Arab nation-building process, this state of affairs implied that the collective group could not be culturally self-sufficient, and had to accept its linguistic inferiority. In short, the Greek narrative was to a certain extent viewed as linguistic colonialism, and as such could not be accepted. In other words, language was the field on whose lines the self-determination process took place, producing the 'us v. them' distinction, i.e., the indigenous Arab self v. the foreign Greek other. Moreover, not being acquainted with the working language, the congregation could not have access to the upper religious bureaucracy, admission to which depended on knowledge of Greek. In effect, language worked as a factor for the reproduction of the existing power relations between the establishment and the congregation, and the linguistic dichotomy within the community reflected the structural hierarchies between the dominant high clergy and the dominated native laity. In other words, the language question was related to power and the question of who would be the agent of this power. The hierarchy did not in principle reject Arabic, but at the same time put limits to its use, because equalizing Arabic with Greek would drive forward the overall claims of the congregation to put an end to the Greek dominance. The question that arises then is: What was the rationale behind the Greek stance of accepting the use of Arabic, but not to such an extent as to elevate Arabic to the same status as Greek?

\section{The Greek Narrative}

My position here is that language, instead of being a cohesive element within the Church, actually worked as a criterion for exclusion. The strategy of not recognizing Arabic as the second official language of the Patriarchate had political, symbolic, and economic foundations. In short, since language had been a crucial factor for legitimizing Greek dominance, giving an equal footing to Arabic would promote Arab nationalism and provide fertile ground for the congregation to further dispute Greek authority and claim an active role in decision-making. In turn, this would lead to the questioning of: a) the 'invented' Greek national character of the institution; b) the management of the vast religious property; and c) the imagined Greek proprietorship of the Holy Places.

In particular, the Greek narrative was based on the idea that Greek dominance was not a modern phenomenon, but was grounded in the continuous use of Greek as the working language of the Patriarchate from the time of its establishment. According to the religious discourse, Greek was given the virtue 
of holiness and thus acquired a sacred character. The use of Greek demonstrated the linear continuity of the institution since the early Church, upon which was founded the primacy of the Patriarchate in the Holy Land, as opposed to the other churches. This was allegedly why, despite the fact that within the Orthodox commonwealth the use of the local vernacular was widespread, by representing Greek as the one official language of the Jerusalem Church, the use of any other tongue, or even worse replacing Greek, would signify a change in the historical normativity and thus the loss of religious purity.

This analytical framework was founded on the 'invented tradition' of Helleno-Orthodoxia, according to which there exists a primordial, and thus essentialist, equation of Orthodoxy with the Greek 'imagined community' Accordingly, in order for someone to be considered a member of the national body, he or she should by definition belong to the Church. One presupposes the other: Greek means Orthodox and viceversa. ${ }^{21}$ Within this analytical framework, developed in the early 2oth century, the native Orthodox population was not considered to be Arab, but was rather seen as an originally ethnically Greek population that had gradually been assimilated linguistically and became Arab-speaking. Their supposed Arab or Aramaic origin was thought to be historically false, ${ }^{22}$ constructed to serve Russian objectives. However, because they denounced their Greek origins, the natives had lost the right to intervene in patriarchal affairs. ${ }^{23}$ In effect, as 'out-groups' the non-Greek Orthodox were not allowed any power over the management of the vast tracts of urban and agricultural real estate, and were not entitled to a share in the revenues derived from their use or lease. ${ }^{24}$

In addition to this, the Greek hierarchy was in favour of the Greek national structure of the Patriarchate forming part of the status quo. Consequently, the

21 Paraskevas Matalas, "To Patriarcheio Hierosolymon kai i ellino-orthodoxia," in Orthodoxia, ethnos kai ideologia, edited by Moraiti School (Athens: Moraiti School, 2007): 116.

22 P. Jouse, "L'Origine des habitants orthodoxes de la Syrie et de la Palestine," Chronos: Revue d'Histoire de l'Université de Balamand IV (2001): 249-273 (First publication: Palestinskii Sbornik XVII,2 (1906): 161-182).

23 Pavlos Karolides, Peri tis ethnikis katagogis ton orthodoxon christianon Syrias kai Palaistinis [On the ethnic origins of the Orthodox Christians of Syria and Palestine] (Athens: P.D. Sakellariou Press, 1909).

24 Itamar Katz and Ruth Kark, "The Greek Orthodox Patriarchate of Jerusalem and its Congregation: Dissent over Real Estate," International Journal of Middle East Studies 37 (2005): 509-534; Itamar Katz and Ruth Kark, "The Church and Landed Property: the Greek Orthodox Patriarchate of Jerusalem," Middle Eastern Studies 43 (2007): 383-408; Konstantinos Papastathis and Ruth Kark, "The Politics of Church Land Administration: the Case of the Orthodox Patriarchate of Jerusalem in Ottoman and Mandatory Palestine," Byzantine and Modern Greek Studies 40/2 (2016): 264-282. 
sanctuaries should not belong to the religious community per se, but to the Greek nation. ${ }^{25}$ This in turn meant that the Patriarchate, as the authority responsible for the administration of the shrines, had to be an exclusive 'club,' admission to which should be restricted solely to Greeks. Given the special significance of the Holy Places for the collective conscience, this status allegedly established a direct link between the national idea and the Christian tradition: since the Greek nation protects the Christian Holy of Holies, Greeks are represented as the new chosen people. The introduction of Arabic in the liturgy would therefore effectively question the myth of Greek proprietorship of the Holy Places, and thus the imagined Greek national superiority. ${ }^{26}$ Within this context, in the following section the areas are examined on which the claim for cultivating Arabic and language equality within the institution were focused, namely the educational system (ideology), religious services (symbolic), and administration (normative).

\section{Language and Education}

Before the mid-nineteenth century, the Orthodox education network was extremely limited. ${ }^{27}$ The Papadopoulos-Kerameus collection of patriarchal documents show that in 1705 Patriarch Dositheos ordered the annual allocation of 160 piastres for the creation of schools in Jerusalem, Gaza, Ramallah, Taybeh, Petzala, Beit Jala, and Kerak. The primary aim of the curriculum was the teaching of both Greek and Arabic. ${ }^{28}$ The operation of the schools was validated by the Patriarch of Constantinople, Gavriil III, the following year. ${ }^{29}$ This was also confirmed by the subsequent patriarch, Chrysanthos, ${ }^{30}$ who according to

25 Kallistos Miliaras, Oi Agioi Topoi en Palaistini kai ta ep' ayton dikaia tou ellinikou ethnous [The Holy Places of Palestine and the rights of the Greek Nation over them] (Thessaloniki; University Studio Press, 2002/reprint); Timotheos Themelis, "Memorandum: Greeks and Franciscans in the Holy Places. 1919," Nea Sion 15 (1920): 381-392.

26 Konstantinos Papastathis, "Religious Politics and Sacred Space: the Orthodox Strategy on the Holy Places Question in Palestine, 1917-1922," Journal of Eastern Christian Studies 65,1/2 (2013): 78-81; Konstantinos Papastathis, "Secularizing the Sacred: the Orthodox Church of Jerusalem as a Representative of Greek Nationalism in the Holy Land," in Modern Greek Studies-Yearbook 2014/15, edited by Theophanis Stavrou (University of Minnesota, 2016), 37-54.

27 Hopwood, The Russian, 101.

28 Papadopoulos-Kerameus, Analecta I (1891), 305-307.

29 Papadopoulos-Kerameus, Analecta I (1891), 379.

3o Papadopoulos-Kerameus, Analecta I (1891), 310-311. 
Stathi was responsible for Dositheos ruling in the first place. ${ }^{31}$ Chrysanthos established a new school in Jaffa as well. ${ }^{32}$ Neophytos of Cyprus testifies that in 1826 the Patriarchate could not operate the school established in St. Nikolaos Monastery in Jerusalem due to budget constraints, and accepted a donation from American Protestant missionaries. The agreement was finally withdrawn however, because the American missionaries were accused of converting the pupils. ${ }^{33}$ This state of affairs led many Orthodox parents to send their children to the schools organized by other denominations (Catholic, Anglican). It is illustrative of this development that $80 \%$ of the pupils at St. George Anglican School were Orthodox. ${ }^{34}$ This in turn contributed to the massive conversion of the indigenous Christian population to Latin, Greek Catholic, and Protestant denominations. Within this context two distinct networks of Orthodox schooling developed, one organized by the Patriarchate and one organized by the Russian Imperial Orthodox Palestine Society.

Within the Patriarchate's network in Palestine and Trans-Jordan the number of schools fluctuated between 20 and 40, depending upon the finances of the institution. Dowling estimated the numbers at 65 boys' schools and 18 girls' schools, ${ }^{35}$ but the operation of at least some of them was 'imagined, ${ }^{36}$ and most of the teachers were untrained parish priests. The language of instruction in Jerusalem schools was Greek, while in Bethlehem, Beit Sahour, Beit Jala and Ramallah schools it was Arabic. On the occasion of the Arab Orthodox protests, Patriarch Hierotheos (1875) circulated an encyclical in which he promised the establishment of a supreme council, comprising six monks and six members of the Jerusalem congregation, for the administration of all the affairs of the schools, including finances. Moreover, he ruled in favour of the creation of a council with an Arab Orthodox majority in each ecclesiastical province for the regulation of the local schools, ${ }^{37}$ but this order was never implemented. In fact, a patriarchal statute (1902) stipulated the creation of an Education Committee comprising only three members, all from the Brotherhood, which

31 Penelopi Stathi, Chrysanthos Notaras patriarchis Ierosolymon: prodromos tou neoeelinikou Diaphotismou [Chrysanthos Notaras Patriarch of Jerusalem: a precursor of neo-Hellenic enlightenment] (Unpublished PhD Thesis: Aristotle University of Thessaloniki, 1995), 153.

32 Papadopoulos-Kerameus, Analecta IV (1897), 58-59.

33 Papadopoulos-Kerameus, Analecta III (1891), 485.

34 Bertram and Young, Report, 148.

35 Theodore Edward Dowling, The Patriarchate of Jerusalem (London: Society for Promoting Christian Knowledge, 1909), 43.

36 Hopwood, The Russian, 141.

37 Timotheos Themelis, Episima eggrafa peri ton dikaion tou Patriarcheiou Ierosolymon (1908-1913) [Official Documents Concerning the Rights of the Patriarchate of Jerusalem (1908-1913)] (Jerusalem: Press of the Convent of the Holy Sepulchre, 1914), 51-52. 
would decide in all Orthodox school affairs. ${ }^{38}$ The Young Turks revolution gave a new impetus to the Orthodox Arabs, who by invoking art. 111 of the restored Ottoman Constitution demanded, among other things, the creation of a Mixed Council with full powers over a number of administrative spheres including the schools system, and the yearly allocation of 60,000 Napoleons in order to cover their various social and educational needs. ${ }^{39}$ In the ensuing negotiations the Brotherhood agreed to this demand. ${ }^{40}$ Finally, the so-called Turkish Order (1910) stipulated the creation of a Mixed Council composed of six lay members and six patriarchal representatives, whose duties included the supervision of all educational activities. However, the Brotherhood retained control of the daily administration as well as the responsibility to appoint school directors and teachers. The Patriarchate, for its part, was ordered to allocate to the Mixed Council one third of its revenues, an amount no less than 30,000 Turkish pounds, "as long as the revenue flow is unhampered." A representative elected by the community of each town was to participate in the administration of the local schools. ${ }^{41}$ Procrastination in the negotiations regarding the Council's functions, and World War I, bequeathed the Orthodox schools problem to the Mandatory authorities. In 1925 the British Commission created to inquire into the national dispute within the Church, proposed the transfer of power over all aspects of the administration of the Orthodox education system (i.e., financial management, direction and supervision of schools, appointment of staff) from the Brotherhood to the Mixed Council, which was just being formed. The British proposed a similar formulation in the Orthodox Patriarchate Draft Amendment Ordinances of 1938 and 1941, without any reaction on the part of the Greek Brotherhood. However, this plan was ultimately abandoned because of Arab Orthodox objections to its overall pro-Greek character. ${ }^{42}$

Poor education was one of the most pressing problems during the Mandate. It is revealing that Arab Orthodox allegations were even acknowledged by the Brotherhood officials. ${ }^{43}$ For this reason, the congregation requested the creation of an elementary schooling network covering as many towns and vil-

38 Bertram and Young, Report, $364-365$.

39 Anton Bertram and Harry C. Luke, Report, 250-251.

40 Themelis, Episima eggrafa, 49, 54.

41 Papastathis and Kark, "Orthodox Communal Politics," 131.

42 Konstantinos Papastathis and Ruth Kark, "Colonialism and Religious Power Politics: The Question of New Regulations within the Orthodox Church of Jerusalem during the British Mandate," Middle Eastern Studies 5o (2014): 589-605.

43 Greek Foreign Office Archives [hereafter G FOA]: File 43/1 Jerusalem, sub-file (4),Jerusalem Consul to the Ministry of Foreign Affairs, num. 10134, 22/4/1920. 
lages as possible, as well as secondary schools in the urban centres. ${ }^{44}$ Except for the self-evident intrinsic value of education, it was also necessary to counteract the conversion activities of the other Churches promoted by their own schools. To this end, English classes were introduced in secondary education, for which however no funding resources were available.

The British had taken full control of the Patriarchate's administration and reduced the funds for education in order to address the financial crisis caused by more than 500,00o Egyptian pounds in debts. ${ }^{45}$ The annual expenditure required by the Brotherhood to maintain its schooling system was roughly estimated by the British to be around $£ 8$, ooo in 1921, while $£ 2,500$ was needed for the teachers' payroll. However, the funds allocated to education for the year 1920 only amounted to $£_{3,750,2,744}$ of which were donated by the Greek government. In contrast, the amount spent on education in 1913 reached $£ 9,186 .{ }^{46}$ Indeed, leading up to 1923 , some of the Arab Orthodox schools had closed. ${ }^{47}$ In 1925 the budget for education was $£_{3,781}$, 960 of which was allocated to the two Greek schools in Jerusalem, and the remainder to the four Arab schools in Bethlehem, Beit Sahour, Beit Jala and Ramallah, the three schools in Transjordan, and the seven village schools in Palestine. It should also be noted that three schools were established and run by the community. ${ }^{48}$ At the end of the thirties, funding for education reached $£_{4,500 .}{ }^{49}$ Nevertheless, teachers were abandoning their jobs, ${ }^{50}$ and requests to open new schools in order to "save the children from the Catholic propaganda," such as that put forward by the community of Nazareth, were all rejected. ${ }^{51}$

Within this context, Orthodox Arabs demanded either the changing of the medium of instruction in the Jerusalem high school from Greek to Arabic, or its closure in order to establish Arab schools. ${ }^{52}$ Their argument was that the

44 Bertram and Young, Report, 144.

45 Konstantinos Papastathis, "Church Finances in the Colonial Age: the Orthodox Patriarchate of Jerusalem under British Control, 1921-1925," Middle Eastern Studies 49 (2013): 712-731.

46 Bertram and Luke, Report, 301-313.

47 GFOA: File 39 (1923), Executive Committee of the First Arab Congress to the Jerusalem Patriarchate.

48 Bertram and Young, Report, 145 .

49 GFOA: File B $/ 36$, File Jerusalem 1929, sub-file 1, Ypomnyma peri tis enestotos katastaseos tou patriarcheioy Ierosolymon.

50 GFOA, File B/36, sub-file 1, Jerusalem General, Jerusalem Consul to the Ministry of Foreign Affairs, no. 524, 24/9/1927.

51 GFOA: File 57.1 (1927), Jerusalem Consul to the Ministry of Foreign Affairs, no. 51, 23/2/1927.

$5^{2}$ GFOA: File 39 (1923), sub-file 3, Jerusalem Consul to the Ministry of Foreign Affairs, no. 535 $(9 / 11 / 1922)$. 
Patriarchate could not afford to spend a large sum of money on just a few students while not providing education to the numerous Arab Orthodox pupils. The Arab proposal involved obtaining financial aid from Athens to operate the Greek schools, so that the Patriarchate could spend revenues allocated for education solely on the Arab schools. ${ }^{53}$ In response to that, Athens stopped making deposits directly to the account of the Patriarchate, but supported its educational activities indirectly through 'donations' to the Jerusalem Greek Club. ${ }^{54}$ This trick allowed the payment of teachers' salaries at the Greek schools, while blocking the congregation's claim to the managing of the patriarchal fund. ${ }^{55}$ Throughout the Mandate, almost each annual volume of the official patriarchal gazette Nea Sion reports a different number of schools operating each year. According to the same gazette, it seems that more schools were operating in Transjordan than in Palestine where the Orthodox community was more numerous. Overall, the Orthodox schooling network was not as popular or influential as the other denominations. This was because of: a) the politicization of communal education, represented as part of the broad controversy between the clergy and the laity; b) the limited teaching of foreign languages (English and French), which was important for the overall training of pupils, but was also a condition for acquiring high offices and a better social position;56 $c$ ) the limited budget; and d) the poor quality of services and facilities in comparison to the other churches' schools.

On the other hand, the Russian network faced certain difficulties in opening schools because of the need to get permission from the Sultan, who refused due to French pressure. Thus, the Russians depended on the Greek Brotherhood, i.e., they needed permission from the Patriarch to operate, who in turn perceived the Imperial Society's activities as an attempt to undermine Greek authority. Patriarchal hostility led the Society to focus its activities more on Syria. From 188 o to 1883 , the Society opened four schools in the region of Nazareth, two girls' schools in Nazareth and Bethlehem, as well as a teachers' seminary to tackle the problem of finding trained Arab and Russian teachers. The language of instruction in Nazareth was mainly Russian, whereas in Bethlehem it was

53 GFOA: File 39 (1923), sub-file 3, Jerusalem Consul to the Ministry of Foreign Affairs, no. 378 $(14 / 7 / 1922)$.

54 The Jerusalem Greek Club was founded in 1902 in Katamon with the support of the Patriarchate and the Greek Consulate. It flourished during the Mandate, when the community reached 3,000 members, and its main fields of activity involved education, sports, organization of social events, and others.

55 GFOA: File 39 (1923), Jerusalem Consul to the Ministry of Foreign Affairs, no. 228 (19/7/1923).

56 Heleen Murre-van den Berg, "The Language of the Nation: The Rise of Arabic among Jews and Christians (1900-1950)," British Journal of Middle Eastern Studies, 43:2 (2016): 176-190. 
Arabic. The curriculum in the training school included the study of Russian, Arabic, Greek and French. ${ }^{57}$ By the 1890 os the schools operating under the aegis of the Imperial Society had reached the number of 23 , with a total enrolment of 1,074 pupils, ${ }^{58}$ who studied free of charge and were also provided with books, pens, etc. ${ }^{99}$ The Russians did not adhere to the colonial conception of their Western counterparts, who taught in English or French, ${ }^{60}$ and the language of instruction was Arabic; Russian was taught in the day schools. ${ }^{61}$ The aim was not the russification of the pupils, but rather the strengthening of their communal identity via the development of the indigenous vernacular. In 1914, the teaching of English and French was introduced in the curriculum as well, in order to counteract the flow of Orthodox pupils to the Catholic and Anglican schools. To conclude, despite its significant influence, the Russian schooling network did not contribute to the educational boom to the same degree as its competitors. It seems that the decision to put emphasis on Syria, due to the obstacles put forward by the Patriarchate and the Great Powers, was a major factor in this outcome.

\section{Arabic in the Liturgy}

From a macro-historical perspective, both Greek and Arabic were always used within the Patriarchate at the church services. Greek had been the liturgical language since the creation of the Church of Jerusalem, and the language of the educated classes in the south-eastern Mediterranean for many centuries. In short, being acquainted with Greek was the medium for acquiring social status and attaining ecclesiastical office. On the other hand, this did not establish a linguistic monopoly. Pilgrim itineraries and ecclesiastical records attest to the translation of the original liturgical texts from Greek to Syriac/ Aramaic (Itinerarium Egeriae) and Arabic. In late Ottoman times, Greek remained the liturgical language in both the Holy Places and in monasteries. On certain occasions, such as the reading of the Epistle and the Gospel in the Holy Sepulchre, or the sermon of John Chrysostom during the holy week, there was

\footnotetext{
57 Theophanes G. Stavrou, Russian Interests in Palestine, 1882-1914: a Study of Religious and Educational Enterprise (Thessaloniki: Institute for Balkan Studies, 1963), 110-114.

58 Stavrou, Russian Interests, 164.

59 Stavrou, Russian Interests, 190.

6o Karène Sanchez Summerer, "Linguistic Diversity and Ideologies among the Catholic Minority in Mandate Palestine. Fear of Confusion or a Powerful Tool?," British Journal of Middle Eastern Studies, 43:2 (2016): 191-205.

61 Hopwood, The Russian, 148.
} 
a simultaneous translation into Arabic. ${ }^{62}$ Moreover, it was customary to have a choir singing psalms in Arabic (the basilica in Bethlehem; the Holy Fire ceremony). Arabic had been established as the liturgical language in the church of Mar-Jacob and in all parish churches. To this end, the printing press of the Patriarchate published a number of liturgical books in Arabic. ${ }^{63}$

In this regard, it is interesting to note that as early as 1908 one of the Arab Orthodox demands was for the extension of the use of Arabic to all religious services, and the establishment of an Arabic choir at the Holy Sepulchre and the other shrines. ${ }^{64}$ However, the Greek Brotherhood rejected the request, probably fearing that Greek would be gradually abandoned. ${ }^{65}$ It was believed that giving space to Arabic rather than calming the locals would fuel their national aspirations. Officially, the Greek establishment justified its stance on the basis of the status quo agreement, which regulates the custodianship rights and privileges of each denomination over the Holy Places, as well as the protocols, processions and all other liturgical practices followed during the services of each cult. The status quo doctrine is based on unquestioning adherence to the arrangement which was established by special edicts $\left(185^{2-1853)}\right.$ and since then has been under the protection of the international community. ${ }^{66}$ In effect, the introduction of an Arabic choir, as a modification of the existing modus operandi, would signify a violation of the status quo. The same would apply if the Greek clergy had changed the language of services in Mar-Jacob from Arabic to Greek. As such, these demands could not be accepted by the political authorities either. The Ottoman stance should not be attributed to domestic politics, but rather to external considerations. The Western powers, being recognized as the protectors of their affiliated churches, used the religious field instrumentally as a means to legitimize their interventions in Palestinian and Ottoman affairs. For instance, an incident between the Orthodox and Franciscan monks in Bethlehem was employed as the pretext for the declaration of the Crimean War. Therefore, any event that might present an opportunity to reopen the question, especially within the volatile political context of the time, was an unwelcome scenario. In short, the rejection of the Arab demands was not only

\footnotetext{
62 Papadopoulos-Kerameus, Analecta II (1893), 200.

63 Bertram and Young, Report, 100-101.

64 Themelis, Episima eggrafa, 64 .

65 Joshua A. Fishman, "A Decalogue of Basic Theoretical Perspectives for a Sociology of Language and Religion," in Explorations in the Sociology, 17-18.

66 Paolo Pieraccini, Gerusalemme, Luoghi Santi e Communità Religiose nella Politica Internazionale (Bologna: Edizioni Dehoniane Bologna, 1997); Walter Zander, "On the Settlement of Disputes about the Christian Holy Places," Israel Law Review 3/3 (1978): $331-366$.
} 
a matter of prestige, but more importantly, had a legal foundation as well as a diplomatic/political background, which could not be circumvented. The same applies to some degree to the question of using Arabic in the administration.

Greek was to all intents and purposes the official language of patriarchal administration and hence of the upper clergy, while Arabic was the everyday language of contact with the laity. Monks spoke other languages as well, as they came from all over the eastern Mediterranean. Needless to say, numerous patriarchs and members of the clergy were natives, having Arabic as their mother tongue and mastering Greek during their youth as novices. However, the use of Arabic was widespread, even after the Ottoman conquest when the Greek element became dominant. Dositheos explicitly states that the minutes of the Synod on Patriarch Germanos' resignation and the election of Sophronios (mid-16th century) were written in Arabic. ${ }^{67}$ The fact that Dositheos does not consider this event strange indicates that the use of Arabic was a normal practice, even in his time. A possible confirmation of this point may be the Arabic signatures of two synodal members on the document confirming the appointment of Patriarch Nectarios (1661). ${ }^{68}$ Furthermore, the large number of Arabic codices in the archives of the Patriarchate is an additional indication of the extended use of the local language. ${ }^{69}$ However, during the late Ottoman period and the Mandate, the Patriarchate gave little room to the use of Arabic in the administration. The one and only ordinance with regard to language is found in the Fundamental Law of the Patriarchate (1875), which defined the knowledge of Arabic as a condition for the appointment of bishops in Acre and Nazareth (art. 15/ par. 4) ${ }^{70}$

Within this context, the strategy of the Orthodox Arabs was, on the one hand, enthusiastically to demand the modification of the Regulations, and on the other hand to expose the illegal practices of the Greek establishment and violations of the existing legal framework. Such a case was the election of

67 Dositheos Patriarch of Jerusalem, Historia peri ton en Hierosolymois patriarcheusanton diirimena en dodeka vivliois, allos kaloumenis dodekavivlos Dositheou (Thessaloniki: Rigopoulos, 1982/reprint), v. vi. b. IA', 50-52, 56, 69 .

68 Papadopoulos-Kerameus, Analecta II (1893), 280.

69 Agamemnon Tselikas, Deltio tou Historikou kai Palaiografikou Archeiou - Katagrafi tou archeiou tou Patriarcheiou Hierosolymon (Athens: MIET, 1992).

70 Timotheos Themelis, Episima eggrafa peri tou proskynimatikou kai dioikitikou kathestotos tis Ecclesias Ieroslymon (Jerusalem: Orthodox Patriarchate Printing Press, 1944), 18. 
Bishop Cleopas in Nazareth, who did not speak Arabic. The congregation considered his election a violation of art. 15 of the Fundamental Law (mentioned earlier), an allegation widely accepted by the British authorities. At the time of this affair, the Orthodox Arabs held a Conference in Haifa (July 1923) where they articulated their overall demands with respect to the Church. ${ }^{71}$ With regard to the language question, they had three claims:

(a) In addition to the Patriarch and the Bishops of Acre and Nazareth, all patriarchal representatives to the Mixed and Local Councils should speak Arabic. ${ }^{72}$

In cases where this regulation was not followed, the appointments should be recalled and the positions filled by the local parochial clergy. The emphasis on the use of Arabic had a political aspect, i.e., projecting the language as a unifying element for the Orthodox population and the Muslim community, and a shared source of identity; hence politicizing language as a means to promote the national agenda. On the other hand, this claim seems to be void in the sense that the Turkish Order (1910), while not questioning the dominance of Greek within the Brotherhood, implicitly recognized the use of Arabic in the Mixed Council and Local Councils. It should be noted that during the inaugural session of the Mixed Council Patriarch Damianos' talk was simultaneously translated into Arabic, and the representatives of the congregation spoke in their native tongue. Moreover, the regulation concerning the election of the representatives was published in both languages. ${ }^{73}$ Thus, it might be inferred that both Arabic and Greek were used as the two working languages of the Mixed Council, and accordingly of the Local Councils as well. If we take into account that only two members of the Synod spoke Arabic fluently, ${ }^{74}$ the issue at stake seems not to be the use of Arabic as such, but the creation of a mechanism to ensure that the linguistic rights of the congregation would be institutionally respected. The Mandatory administration actually supported this claim by proposing knowledge of Arabic as a condition for the appointment of all bishops as early as $1926 .{ }^{75}$

(b) Cleopas' nomination should be annulled.

\footnotetext{
71 Bertram and Young, Report, 273-278.

72 Bertram and Young, Report, $115-117$.

73 Themelis, Episima eggrafa, $70-80$.

74 GFOA: File B/36, File Jerusalem-Patriarchal Question 1929, Jerusalem Consul to the Ministry of Foreign Affairs, no. 298, 17/6/1929.

75 Bertram and Young, Report, 299.
} 
The fact that the election of Cleopas was contrary to the Fundamental Law of the Patriarchate meant that the synodal decision violated the status quo. However, despite this legal constraint Cleopas remained in office because there were no legal means to impose his immediate deposition. Neither the authorities nor the congregation had an official say in his election or the right to confirm the procedure. In effect, they could only take the matter to court. However, the competent authority to judge on any affair related to the status quo was neither the local courts nor the High Commissioner, but the socalled Holy Places Commission as defined by art. 14 of the Palestine Mandate. This commission had never been established, because London considered it a potential threat to its rule over Palestine, and because of a disagreement within the international community regarding its composition. ${ }^{76}$ In effect, the only body empowered to withdraw the nomination of the bishop was the Patriarchal Synod. However, Damianos refused to appoint another prelate, because he aimed to isolate Cleopas from Jerusalem and the Brotherhood due to their difficult relationship. ${ }^{77}$ The affair ended in 1929 when Cleopas died under suspicious circumstances. ${ }^{78}$

(c) Church law should be translated into Arabic.

The ecclesiastical judicial system comprised two bodies: the Spiritual Court and the Mixed Ecclesiastical Court in each diocese (Jerusalem, Acre, Haifa, Nazareth, Jaffa, Gaza, etc.). The president was the local Greek bishop, but in both courts the congregations' representatives, either parish priests or laymen, retained the majority. Thus Arabic, together with Greek, was widely accepted as a working language of the communal judiciary. ${ }^{79}$ In this regard, it is interesting to note that Arabic was used in the Ecclesiastical Court of Nazareth, presided over by the parish priest Georgios during the period the See was vacant after Cleopas' death. ${ }^{80}$

The language of the religious judiciary became an extremely important issue during the Mandate period because of the extension of the Ecclesiastical

\footnotetext{
76 Zander, "On the Settlement."

77 GFOA: File 39, Jerusalem Consul to the Ministry of Foreign Affairs, no. 231 (25/6/1923).

78 GFOA: File B/36, Politics Jerusalem (1929), Jerusalem Consul to the Ministry of Foreign Affairs, no. 579 (30/9/1929).

79 Orthodox Patriarchate of Jerusalem Archives [hereafter OPJA], File High Commission, Locum Tenens of the Patriarchate to the Chief Secretary of the Mandatory Government, no. 64 31/1/1931.

80 OPJA: File High Commission, Locum Tenens of the Patriarchate to the Chief Secretary of the Mandatory Government, no. 114 18/2/1932).
} 
Courts' jurisdiction. The British decision had been determined by an overall strategy to exploit or further develop existing internal divisions within Palestinian society, which was not seen by the new regime as a coherent collective body, but as a juxtaposition of distinct communities divided along sectarian lines. To this end, the British maintained the millet system. ${ }^{81}$ Practically speaking, the legislator, instead of absorbing the competences of religious courts as a step towards legal modernization, gave the religious institutions extra fields in which to exercise judicial control. In particular, under the Ottoman legal system, Orthodox subjects were exclusively under the jurisdiction of ecclesiastical courts in matters of family (marriage, divorce, adoption of minors, etc.) and inheritance, whereas in all other cases the Ottoman civil jurisdiction was deemed competent to judge. However, the Palestine Order in Council 1922, the Succession Ordinance 1923, and the Jurisdiction of Civil and Religious Courts Ordinance (1924) prescribed that the ecclesiastical courts should not only maintain the right to judge family and inheritance law affairs, but must also assume the adjudication of disputes concerning the administration of the $v a k f$ properties. ${ }^{82}$

The problem lay in the fact that under the Ottomans, the judicial power to settle affairs related to the $v a k f$ administration was tried by the Sharia court, so that the legal framework was in Arabic. The British transferred this power to the ecclesiastical courts, which based their verdicts on the Byzantine and Canon law, written in Greek. In effect, the congregation had no access to the relevant legal sources, and as such was vulnerable to pressure. Hence, instead of safeguarding open access and equal footing within the legal system for the community, the new system gave a further boost to the authority of the Greek establishment. The inability of the local population to participate in the judicial process because of a lack of knowledge of Greek rendered the Arab Orthodox reliant upon the upper clergy for questions far from the clergy's competences, such as the distribution of family revenues or the management of family properties. This state of affairs in turn worked as a breeding ground for arbitrary decisions, corruption and clientelism. ${ }^{83} \mathrm{~A}$ characteristic example was the private prosecution of the Bishop of Madava, Meliton, at the Magistrates' Court in

\footnotetext{
81 Rashid Khalidi, The Iron Cage: the Story of the Palestinian Struggle for Statehood (Oxford: Oneworld Publications, 2007), 48-64.

82 Daphne Tsimhoni, "The Status of the Arab Christians under the British Mandate in Palestine," Middle Eastern Studies 20 (1984): 169.

83 Israel State Archives [hereafter ISA]: File: b/22/35, 4309/26-n, Complaint against the orthodox ecclesiastical courts (1935-1945).
} 
Acre, who was accused of fraud and forgery during his time as President of the Ecclesiastical Court of Appeal. ${ }^{84}$

The claim for access to legal texts was not only a matter of justice, but was directly related to the overall secularization process. Understanding the law meant that litigants considered themselves to be able to properly interpret a text (which used to be the privilege of the religious bureaucracy), as well as to assess the court's verdict, thus undermining the symbolic authority of the ecclesiastical tribunal. In this regard it is important to note that as early as 1862 family law and inheritance law cases were settled by the ecclesiastical courts according to the Byzantine legal code, with which the congregation was not familiar anyway. The request to translate the legal code was first and foremost based on the idea that the religious authority was not unquestionable, and that its decisions should be placed under scrutiny. The Arab Orthodox demand was not in principle rejected by the Greek establishment. However, due to a lack of funding, ${ }^{85}$ in the 1930 s the British decided to translate the legal codices of family, cessation and Personal law of the Byzantine Legal Code themselves. ${ }^{86}$

To sum up, from the mid-nineteenth century onward the congregation had energetically presented the demand for the use of Arabic in schools, church administration, and liturgy to the Greek Brotherhood. The Patriarchate, for its part, had no other option but to accept it, in light of the fact that speaking Arabic in all fields of religious activity was practically a fait accompli. In short, the religious establishment could neither impose on its congregation the use of a language they did not understand, nor did it have the intention to hellenise the Arab Orthodox linguistically. Arabic was the basic medium for instruction in schools, had been used for liturgical purposes for centuries, and was spoken within the Brotherhood. On the other hand, Arabic had never been officially recognised as equal to Greek.

\footnotetext{
84 GFOA: File B/36/1, Patriarchal Election Jerusalem (1934), Benetatos to the Greek Foreign Office (24 December 1934), reg. num. 13830; Public Record Office: Colonial Office [CO] 733/ 258/11, 'Wauchope to Cunliffe-Lister' (30 Nov. 1934).

85 Bertram and Young, Report, 209.

86 ISA: File: b/34/33, 25/5-n, Orthodox patriarchate - protest against by the orthodox youth club, Jerusalem (11/1928-4/1933), Protest of the Orthodox Youth Club: a request for the immediate execution of Sir Anton Bertram's Report (6/11/1928)
} 


\section{$7 \quad$ Concluding Remarks}

The controversy between the Greek hierarchy and the Arab congregation had a political, economic, and a social background. In this chapter I have discussed the question of how the use of language within the Jerusalem Church, and particularly in the spheres of education, church services, and administration was related to the secularization and nationalization processes of the Orthodox Palestinians. Overall, I have argued that while the Arabic vernacular was widely used in religious services, as a medium of instruction, and as a working language in the administration, it did not enjoy the same status as Greek. The Greek Brotherhood accepted the need to further develop the use of Arabic, but was against granting Arabic the status of an official language of the Patriarchate. Such a decision would in the long run entail questioning the exclusivity of the Greek dominance within the institution. The refutation of the Arab claims, therefore, was founded on the hegemony of Greek phyletism within the Church.

\section{Bibliography}

\section{Archives}

British Public Record Office:

Colonial Office [CO] 733/258/11.

Greek Foreign Office Archives:

File 43/1 Jerusalem, sub-file (4).

File 39 (1923), sub-file 3.

File B/36, File Jerusalem 1929, sub-file 1 .

File B/36, sub-file 1, Jerusalem General.

File B/36, File Jerusalem-Patriarchal Question 1929 .

File B/36, Politics Jerusalem (1929).

File 57.1 (1927).

File B/36/1, Patriarchal Election Jerusalem (1934).

Israel State Archives:

File: $b / 22 / 35$.

File: $b / 34 / 33$.

Orthodox Patriarchate of Jerusalem Archives:

File High Commission 


\section{Secondary Literature}

'A. al-Aḥad al-Shāfī, A. Lamḥa ta'rīkhiyya fì akhawiyya al-qabr al-muqaddas al-yūnāniyya. Beirut, 1893 [translated by Michel Najim, An Historical Glance at the Brotherhood of the Holy Sepulcher. California, 1996].

Astafieva, Elena. "La Russie en Terre Sainte: le cas de la Société Impériale Orthodoxe de Palestine (1882-1917)." Cristianesimo nella Storia 24 (2003): 41-68.

Barron, J.B. Palestine: Report and General Abstracts of the Census of 1922 (Government of Palestine, 1923).

Bawalsa, Nadim. "Sakakini Defrocked." Jerusalem Quarterly 42 (2010): 5-25.

Ben-Arieh, Yehoshua. "Patterns of Christian Activity and Dispersion in Nineteenth Century Jerusalem." Journal of Historical Geography 2,1 (1976): 49-69.

Bertram, Anton and John W.A. Young. The Orthodox Patriarchate of Jerusalem: Report of the Commission Appointed by the Government of Palestine to Inquire and Report upon Certain Controversies between the Orthodox Patriarchate of Jerusalem and the Arab Orthodox Community. London: Oxford University Press, 1926.

Bolkvadze, Tinatin. "Eastern Christian Tradition and the Georgian Language." in Explorations in the Sociology of Language and Religion, edited by Tope Omoniyi and Joshua A. Fishman, 6o-67. Amsterdam/Philadelphia: John Benjamin Publishing House, 2006.

Bracy, Michael. Printing Class: Isa Al-Isa, Filastin, and the Textual Construction of National Identity, 1911-1931. Lanham: University Press of America, 2011.

Dositheos Patriarch of Jerusalem. Historia peri ton en Hierosolymois patriarcheusanton diirimena en dodeka vivliois, allos kaloumenis dodekavivlos Dositheou. Thessaloniki: Rigopoulos, 1982/reprint.

Dowling, Theodore Edward. The Patriarchate of Jerusalem. London: Society for Promoting Christian Knowledge, 1909.

Fishman, Joshua A. "A Decalogue of Basic Theoretical Perspectives for a Sociology of Language and Religion." In Explorations in the Sociology of Language and Religion, edited by Tope Omoniyi and Joshua A. Fishman, 13-25. Amsterdam/Philadelphia: John Benjamin Publishing House, 2006.

Haiduc-Dale, Noah. Arab Christians in British Mandate Palestine: Communalism and Nationalism, 1917-1948. Edinburgh: Edinburgh University Press, 2013.

Hopwood, Derek. The Russian Presence in Syria and Palestine, 1843-1914: Church and Politics in the Near East. Oxford: Clarendon Press, 1969.

Jouse, P. "L'Origine des habitants orthodoxes de la Syrie et de la Palestine." Chronos: Revue d'Histoire de l'Université de Balamand IV (2001): 249-273. (First publication: Palestinskii Sbornik, XVII, fasc. 2 (1906): 161-182). 
Miliaras, Kallistos. "Character and Composition of the Patriarchate of Jerusalem." In Report of the Commission Appointed by the Government of Palestine to Inquire into the Affairs of the Orthodox Patriarchate of Jerusalem, edited by Anton Bertram and Harry C. Luke, 284-291. London: Oxford University Press, 1921.

Miliaras, Kallistos. Oi Agioi Topoi en Palaistini kai ta ep' ayton dikaia tou ellinikou ethnous [The Holy Places of Palestine and the rights of the Greek Nation over them]. Thessaloniki; University Studio Press, 2002/reprint.

Karolides, Pavlos. Peri tis ethnikis katagogis ton orthodoxon christianon Syrias kai Palaistinis [On the ethnic origins of the Orthodox Christians of Syria and Palestine]. Athens: P.D. Sakellariou Press, 1909.

Katz, Itamar and Ruth Kark. "The Greek Orthodox Patriarchate of Jerusalem and its Congregation: Dissent over Real Estate." International Journal of Middle East Studies 37 (2005): 509-534.

Katz, Itamar and Ruth Kark. "The Church and Landed Property: the Greek Orthodox Patriarchate of Jerusalem." Middle Eastern Studies 43 (2007): 383-408.

Kedourie, Elie. "Religion and Politics." In The Chatham House Version and Other Middle Eastern Studies, 317-342. Chicago: Ivan R. Dee, 2004.

Khalaf, Noha Tadros. Les Memoires de Issa al Issa:Journaliste et Intellectuel Palestinien 1878-1950. Paris: Editions Karthala, 2009.

Khalidi, Rashid. The Iron Cage: the Story of the Palestinian Struggle for Statehood. Oxford: Oneworld Publications, 2007.

Konortas, Paraskevas. Othomanikes theoriseis gia to Oikoumeniko Patriarcheio, 170 - arches $200 u$ aiona [Ottoman vetting concerning the Ecumenical Patriarchate, 17th - beginning of the 2oth century]. Athens: Alexandreia, 1998.

Mack, Merav, Angelos Dalachanis, and Vincent Lemire. "Matrimony and Baptism: Changing Landscapes in Greek (Rum) Orthodox Jerusalem (1900-1940)." British Journal of Middle Eastern Studies 45,3 (2018): 443-463; online Jan. 2017: 1-21.

Murre-van den Berg, Heleen. "The Language of the Nation: The Rise of Arabic among Jews and Christians (1900-1950)." British Journal of Middle Eastern Studies 43,2 (2016): 176-190.

Papadopoulos-Kerameus, Athanasios. Analekta hierosolymitikēs stachiologias. Petersburg: Vol. I, 1891; vol. II 1894, vol. III, 1897; vol. IV, 1897.

Papastathis, Konstantinos. "Religious Politics and Sacred Space: the Orthodox Strategy on the Holy Places Question in Palestine, 1917-1922." Journal of Eastern Christian Studies 65,1/2 (2013): 78-81.

Papastathis, Konstantinos. "Church Finances in the Colonial Age: the Orthodox Patriarchate of Jerusalem under British Control, 1921-1925." Middle Eastern Studies 49 (2013): 712-731.

Papastathis, Konstantinos. "Secularizing the Sacred: the Orthodox Church of Jerusalem as a Representative of Greek Nationalism in the Holy Land." In Modern 
Greek Studies-Yearbook 2014/15, edited by Theophanis Stavrou, 37-54. University of Minnesota, 2016.

Papastathis, Konstantinos. "Religious Politics in Mandate Palestine: The Christian Orthodox Community Controversy in the Thirties." British Journal of Middle Eastern Studies 43,3 (2016): 259-284.

Papastathis, Konstantinos. "Constructing the 'intra-communal out-group': the Greek religious imperialism and the Arab Orthodox 'quantité négligeable." In Middle Eastern Christians and Europe: Diasporas - Relations - Entangled Histories, edited by Andreas Schmoller. Berlin et.al.: Lit, forthcoming.

Papastathis, Konstantinos and Ruth Kark. "Orthodox Communal Politics in Palestine after the Young Turk Revolution (1908-1910)." Jerusalem Quarterly 56/57 (2014):118-39.

Papastathis, Konstantinos and Ruth Kark. "Colonialism and Religious Power Politics: The Question of New Regulations within the Orthodox Church of Jerusalem during the British Mandate," Middle Eastern Studies 5o (2014):589-605.

Papastathis, Konstantinos and Ruth Kark. "The Politics of Church Land Administration: the Case of the Orthodox Patriarchate of Jerusalem in Ottoman and Mandatory Palestine." Byzantine and Modern Greek Studies 40,2 (2016): 264-282.

Matalas, Paraskevas. "To Patriarcheio Hierosolymon kai i ellino-orthodoxia." In Orthodoxia, ethnos kai ideologia, edited by Moraiti School, 113-121. Athens: Moraiti School, 2007.

Pieraccini, Paolo. Gerusalemme, Luoghi Santi e Communità Religiose nella Politica Internazionale. Bologna: Edizioni Dehoniane Bologna, 1997.

Robson, Laura. "Communalism and Nationalism in the Mandate: The Greek Orthodox Controversy and the National Movement." Journal of Palestine Studies XLI (2011): $6-23$.

Roussos, Sotiris. "The Greek Orthodox Patriarchate and Community of Jerusalem." In The Christian Heritage in the Holy Land, edited by A. O'Mahony, G. Gunner and K. Hintlian, 211-224. London, 1995.

Roussos, Sotiris. "The Greek Orthodox Patriarchate and Community of Jerusalem: Church, State and Identity." In The Christian Communities in Jerusalem and the Holy Land: Studies in History, Religion and Politics, ed. A. O'Mahony, 38-56. Cardiff, 2003. Roussos, Sotiris. "Eastern Orthodox Perspectives on Church-State Relations and Religion and Politics in Modern Jerusalem." International Journal for the Study of the Christian Church 5 (2005): 103-122.

Sakakini, Khalil. The Diaries of Khalil Sakakini (Volume II: Orthodox Renaissance, World War I, Exile to Damascus), edited by Akram Mousallam. Ramallah: Khalil Sakakini Cultural Centre, and the Institute for Jerusalem Studies, 2004.

Sanchez Summerer, Karène. "Linguistic Diversity and Ideologies among the Catholic Minority in Mandate Palestine. Fear of Confusion or a Powerful Tool?," British Journal of Middle Eastern Studies 43,2 (2016): 191-205. 
Stamatopoulos, Demetres. Metarrythmisi kai ekkosmikeusi: pros mia anasynthesi tis historias tou Oikoumenikou Patriarcheiou ton 190 aiona [Reformation and secularization: towards a reformulation of the history of the Ecumenical Patriarchate in the 19th century]. Athens: Alexandria, 2003.

Stathi, Penelopi. Chrysanthos Notaras patriarchis Ierosolymon: prodromos tou neoeelinikou Diaphotismou [Chrysanthos Notaras Patriarch of Jerusalem: a precursor of neo-Hellenic enlightenment]. Unpublished $\mathrm{PhD}$ Thesis: Aristotle University of Thessaloniki, 1995 .

Stavrou, Theophanes G. Russian Interests in Palestine, 1882-1914: a Study of Religious and Educational Enterprise. Thessaloniki: Institute for Balkan Studies, 1963.

Tamari, Salim. "Issa al Issa's Unorthodox Orthodoxy: Banned in Jerusalem, Permitted in Jaffa." Jerusalem Quarterly 59 (2014): 16-36.

Themelis, Timotheos. Episima eggrafa peri ton dikaion tou Patriarcheiou Ierosolymon. 1908-1913) [Official Documents Concerning the Rights of the Patriarchate of Jerusalem (1908-1913)]. Jerusalem: Press of the Convent of the Holy Sepulchre, 1914.

Themelis, Timotheos. "Memorandum: Greeks and Franciscans in the Holy Places. 1919." Nea Sion 15 (1920): 381-392.

Themelis, Timotheos. Episima eggrafa peri tou proskynimatikou kai dioikitikou kathestotos tis Ecclesias Ieroslymon. Jerusalem: Orthodox Patriarchate Printing Press, 1944.

Tibawi, Abdul Latif. Russian Cultural Penetration of Syria-Palestine in the Nineteenth Century. London: Luzav and Co., 1966.

Tselikas, Agamemnon. Deltio tou Historikou kai Palaiografikou Archeiou-Katagrafi tou archeiou tou Patriarcheiou Hierosolymon. Athens: MIET, 1992.

Tsimhoni, Daphne. "The Greek Orthodox Patriarchate of Jerusalem during the Formative Years of the British Mandate in Palestine." Asian and African Studies 12 (1978): 77-121.

Tsimhoni, Daphne. "The Status of the Arab Christians under the British Mandate in Palestine." Middle Eastern Studies 20 (1984): 166-192.

Vatikiotis, P.J. "The Greek Orthodox Patriarchate of Jerusalem between Hellenism and Arabism." Middle Eastern Studies 20 (Oct. 1994): 916-929.

Young, George. Corps de Droit Ottoman. Oxford: Clarendon Press, 1905.

Zander, Walter. “On the Settlement of Disputes about the Christian Holy Places.” Israel Law Review 3,3 (1978): 331-366. 